\title{
Kali Gandaki 'A' Hydroelectric Project in Environmental Perspectives
}

\author{
Rajendra P. Thanju
}

$\mathbf{H}$ ydropower is one of the cleanest, renewable and environmentally benign sources of energy. Nepal is blessed with immense source of water resources and huge hydropower potential. Kali Gandaki 'A' Hydroelectric Project is the largest hydropower project implemented so far in Nepal. The project is located in the Western Development Region of Nepal. The main component of the project is located at Syangja District in Gandaki Zone, and other components partially encompass other districts such as Gulmi, Palpa, Parbat, Kaski and Rupandehi.

The feasibility study of the project was carried out in 1979 with the financial assistance from United Nations Development Program (UNDP) which was updated in 1991. The detailed engineering design and preparation of tender documents commenced in 1993 with the financial assistance of Asian Development Bank (ADB), United Nation Development Program (UNDP) and Finnish International Development Agency (FINNIDA) jointly. The preparatory works like access road construction was started in 1993 with internal resources from Government of Nepal and Nepal Electricity Authority (NEA).

The construction works were divided into seven lots. Impregilo SpA (IgL), Italy, was the civil contractor (for lot C1, C2 and C3); Noell Stahl-und Maschinenbau, Germany, for Hydraulic Steel works (Lot 4); France/J apan J V of Mitsui/Toshiba/ Alstom (Former CEGELEC), for Electrical Works (Lot 5); J apan joint venture of Mitsui/ Toshiba for Mechanical works (Lot 6); and TATA International / Marubeni, J apan, were the contractors for transmission line and substation works (lot-7), respectively. The project is owned and operated by the Nepal Electricity Authority (NEA). The project engineers were Morrison Knudsen International Inc., USA, in association with Norconsult International, Norway, and IVO International, Finland.

Construction of the hydropower component was started in 1997 under the loan assistance of Asian Development Bank (ADB) and Overseas Economic Corporation Fund (OECF, now known as J apan Bank for International Cooperation, or J BIC). The project construction work was completed in 2002. The

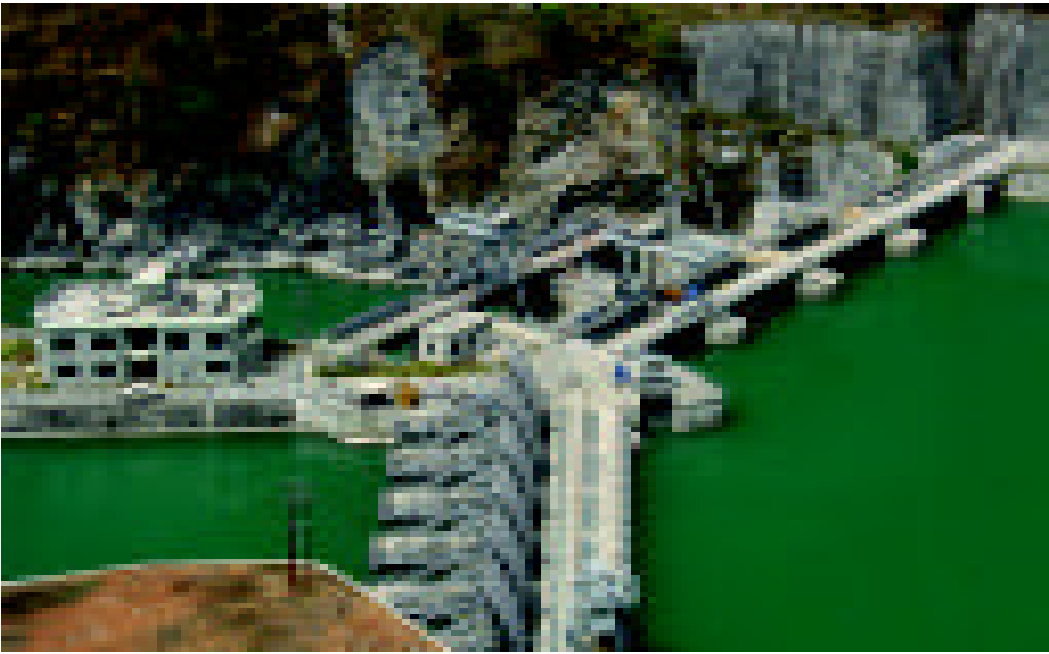

Figure 1. View of Kali Gandaki Dam

generation unit was tested in May 2002 and commercial production began from August 2002.

\section{Project features}

The major project components include hydropower dam and powerhouse, project access road, transmission line and substations, as described below.

\section{Hydropower}

Kali Gandaki 'A' Hydroelectric Project is a daily pondage type scheme located on the Kali Gandaki River with an installed capacity of $144 \mathrm{MW}$. The project generates about 842 GWh of electric energy annually by utilizing a net head of $115 \mathrm{~m}$. The main structures of the project are concrete gravity diversion dam about $100 \mathrm{~m}$ long and $43 \mathrm{~m}$ high, open surface desander, headrace tunnel of about $6 \mathrm{~km}$ in length and $7.4 \mathrm{~m}$ diameter, and a surface powerhouse. The rated discharge of $141 \mathrm{~m}^{3} / \mathrm{s}$ feeds three Francis type turbines in the powerhouse. The surface area of the reservoir is $65 \mathrm{ha}$, followed by a $5.3 \mathrm{~km}$ long back water level. Permanent camps are located at Beltari and Mirmi in the Shree Krishna Gandaki Village Development Committee (VDC) of Syangja District. 


\section{Access road}

The access road of the project crosses steep and hilly terrain. Total length of the access roads is about $28.5 \mathrm{~km}$. The access road starts from Batuwa, $82 \mathrm{~km}$ from Pokhara on Siddhartha highway (3.5 south of Galyang Bazaar) and ends at the left bank of the dam, which is about $20 \mathrm{~km}$ away from the highway. The access road for the powerhouse branch out from J aipate is about $8 \mathrm{~km}$ long.

\section{Transmission lines}

The power generated from the project by 3 units of turbines of $48 \mathrm{MW}$ each capacity is evacuated to the central grid via a $132 \mathrm{kV}$ single circuit, a $66 \mathrm{~km}$ long transmission line to Pokhara and a $44 \mathrm{~km}$ double circuit transmission line to Butwal. A sub-station is constructed at Lekhnath Municipality of Kaski District, whereas the pre-existingJ ogikuti substation of Butwal has been upgraded.

\section{Environmental studies}

From the initial stage of project, environmental concerns were the integral part of design optimization. The environmental studies/activities of the project during pre-project, construction stage and operation phase are briefly described below.

\section{Pre-project phase}

The Environmental Impact Assessment (EIA) study was conducted in 1996 according to National EIA Guidelines of 1993 and Asian Development Bank Guidelines of 1990. The report was duly approved by the Asian Development Bank (ADB).

Theinteraction and consultation programs during the project preparation stage reflected views of different stakeholders, which were considered in the detailed design phase of the project, and possible

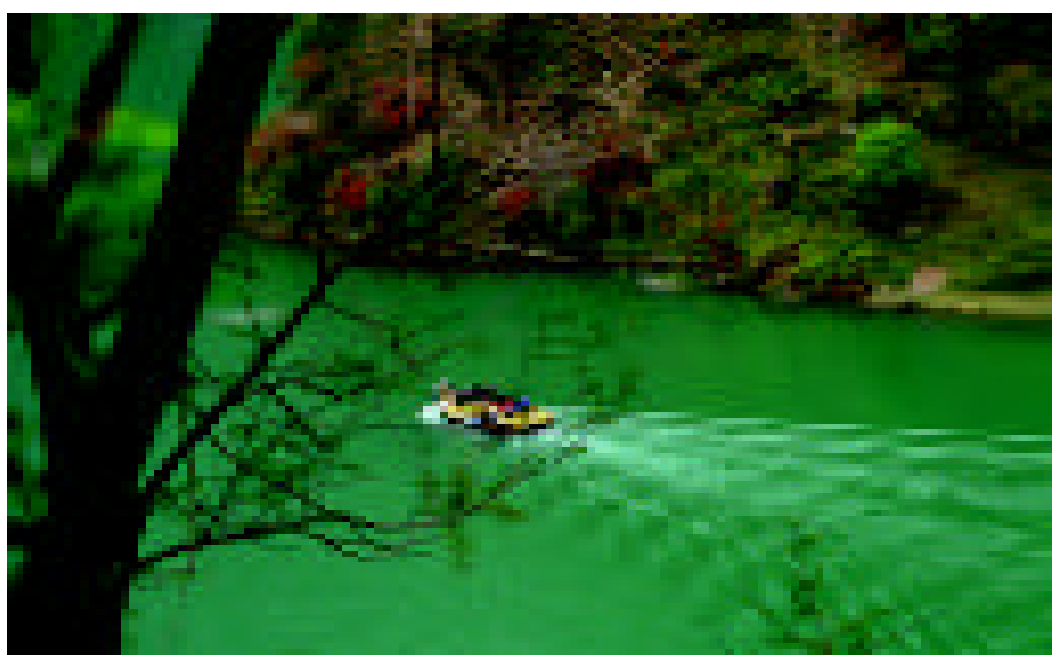

Figure 2. Boat transportation in project reservoir adverse environmental impacts were avoided to the extent possible.

\section{Environmental documents}

From the beginning, environmental consideration was given priority in the project. Various environmental documents were prepared during engineering design and tender documents preparation. The primary documents that guided environmental activities of the project are given below. These documents were used in cross-reference with each other:

- Environmental Impact Assessment (EIA), Vol. 1-2, 1996.

- Mitigation Management and Monitoring Plan (MMMP), 1996.

- Acquisition, Compensation and Rehabilitation Plan (ACRP), 1996.

- Tender documents with conditions of particular applications, including social and environmental clauses.

- ADB: Summary Environment Impact Assessment (SEIA), 1996

- ADB: Report and Recommendation of President to Board of Directors, 1996 RRP-NEP 26362)

- Loan Agreement with ADB

The EIA explained the impacts and proposed mitigation measures as identified during the detail study of the project and provides justification for the mitigation. The MMMP described how the mitigation spelled out in the EIA, ACRP and in Tender Clauses will be carried out. The MMMP provided a guide to mitigation management and environmental monitoring. The main objective of ACRP was to insure that people affected by project-related property and land acquisitions would be as well off after the project as they were before. The Tender Documents specified what action construction contractors were required to take to protect the environment.

In addition, the contractors were required to develop an Environmental Protection Plan, a Health and Safety Plan and a Waste Management Plan, and contractors disturbing vegetation were required to submit a Revegetation Plan. These Plans augmented the MMMP and specified how the contractors met and implemented the environmental 
EIA, ACRP and the Tender Documents.

The loan document between ADB and NEA defined the role, responsibility and mandate of Kali Gandaki Environmental Management Unit (KGEMU). Theloan document included basic provisions in environmental aspects, which were to be carefully addressed to comply with ADB's policies and procedures. Included in this document are: institutional requirement for monitoring; establishment of the KGEMU; provision for a construction stage International Panel of Experts $(\mathrm{POE})^{1}$ on environmental and social aspects; implementation of MMMP; contractors' compliance with tender clauses; compensatory flow of $4 \mathrm{~m}^{3} / \mathrm{s}$; operation and management of a fish hatchery program; and clauses regarding minimization of resettlement, enabling communities to benefit from the project, preferential hiring, and the need for public consultation.

Social mitigation policy

The Resettlement Policy defined in project documents provides that the Government of Nepal and the NEA shall take or cause to be taken all necessary measures to ensure that all the population adversely affected by carrying out the project shall generally:

- improve or at least regain their prior standard of living;

- be relocated, if necessary, in accordance with their preferences and be fully integrated into the community in which they move; and

- be provided with appropriate, agreed upon compensation and required physical rehabilitation of infrastructures, community facilities, including rehabilitation grants, skill training and employment opportunities. All such measures should at least satisfy the requirement of the ACRP.

\section{Environmental impacts}

Major impacts occurred due to the implementation of the project on physical, biological and socioeconomic and cultural environment are summarized below:

Physical environment

- Submergence of forest land and other land uses due to creation of $5.3 \mathrm{~km}$ long (65 ha) reservoir.

- Hydrological changes in the $13 \mathrm{~km}$ stretch downstream between the dam and the confluence with the major tributary, Badi Gad.

- Impacts on hydrology downstream of the power plant are restricted to the dry season when the facility is used for peaking. The changes in flow and stage pose hazards to water users immediately below the power plant site.

- Generation of 6.2 million tons of muck/ spoil.

Biological environment

- Removal of 6,093 trees of various species (khayar, bakaino, ipil-ipil, simal, sissoo and sal) due to implementation of the project.

- Soil erosion and land slides due to project construction works.

- Loss of wildlife habitat around dam, powerhouse sites and nearby areas.

- Impact on migration of long range migratory fishes due to damming of river.

Social/ cultural environment

- Loss of approximately 208.68 ha of land due to placement of project structures and facilities, including access road.

- Altogether 1,468 families lost their land (or part of it), their houses, or both, out of which 263 families were defined as $\mathrm{SPAF}^{2}$ and 1,205 families as $\mathrm{PAF}^{3}$.

- Impacts to indigenous Bote (fisherman) community. About 21 houses, 5 cowshed and approximately 13 ropani of land from the Bote families were acquired.

- Impact on Setibeni Sheela, a religious site.

- Reduction of white water rafting in Kali Gandaki River from 5 days to 3 days.

\section{Environmental monitoring and mitigation management}

The Nepal Electricity Authority, project engineers and contractors were responsible for the monitoring and implementation and management of mitigation measures. KGEMU was the key unit established under the consultant umbrella to monitor environmental mitigation measures carried out by contractors, to carry out environmental mitigation programs and conduct environmental monitoring during the construction phase, as spelled out in EIA, MMMP and Tender Documents.

The environmental monitoring and mitigation management activities carried out during the project construction stage are briefly described below.

Kali Gandaki Environmental Management Unit (KGEMU)

The KGEMU was formed in J anuary 1997 with the commencement of project construction. It was the first organization of its kind in hydropower projects 
in Nepal to monitor and mitigate the adverse environmental impacts due to the project construction and was established as per the provision in the loan agreement between NEA and ADB. Considering multidimensional activities and mandate, KGEMU was staffed with a diverse group of environmental professionals. The environmental advisor and trainer, an expatriate position, was responsible for reviewing the performance and manage KGEMU for the first year. Moreover, an expatriate manager and an International Panel of Experts (environmental and social) were also engaged to guide and review the environmental and social works of the project throughout the project construction stage.

Monitoring activities were considered an important aspect. KGEMU staff conducted compliance monitoring of the international contractors regarding environmental obligations as mentioned in the contract documents. About 108 environmental and social clauses were incorporated in tender documents of the civil contractor (IgL).

Significant shortcomings on the part of contractors were documented and informed to the relevant contractors for necessary improvements. Several engineer's instructions were issued to the contractors to make them comply with their contractual obligations. However, the contractors' environmental compliance status was satisfactory, but needs greater enforcement mechanism to achieve better performance in future projects.

Social research and impacts studies

The professional staff of the KGEMU conducted several impacts monitoring studies among the affected populace of the project areas during the period of the project construction. This research effort paid off handsomely, resulting in about 18-20 studies on various types of social impacts, a research record rarely achieved in other hydropower projects (POE 2002). The findings of these researches on impacts and issues were conveyed to the project director and the ADB, through POE reports and ADB Supervision Mission reports.

Mitigation implementation/ adaptive management

The project mostly followed the mitigation approaches proposed by the project environmental documents. Nevertheless, the project also espouse to adaptive management approach in order to minimize and/ or mitigate the unforeseen adverse impacts arises during the course of project implementation. Resettlement and Rehabilitation program for affected Bote (Fishermen) families and implementation of Community Support Program were good examples of adaptive management of the project. Some of the major mitigation measures implemented and/ or constructed during construction stage of the project were as follows;

Physical Environment

- Installation of siren warning system in powerhouse and dam site.

- Protection measures for water qu-ality at project areas.

- Restoration of the disturbed site using bioengineering measures at head work site, powerhouse site, access road and transmission line tower locations.

- Management and control of 6.2 million tons excavated materials were carried out as per the approved plan submitted by the contractor.

Biological environment

- Establishment of project central nursery with production capacity of 60,000 seedlings/year and grass slip production (150,000-200,000/year) for bioengineering and slope stabilization purposes in project site.

- Establishment of satellite nurseries to provide seedlings to local communities.

- Plantation of 319,694 seedlings of different species at different project components and community land.

- Restriction on hunting and poaching during construction period of the project.

- Construction of fish hatchery.

- Implementation of fish trapping and hauling program.

- Construction of trash rack, fish bypass system and collector channel at headwork site.

Social/ cultural environment

- Cash compensation for the loss of land, house and other assets. The formal tenants of guthi (communal) land were paid an additional $42 \%$ compensation, totaling 75\% vis-à-vis legal provision of only 33\% compensation. Compensation also provided for standing crops and grass damaged during the project construction.

- Provided additional rehabilitat-ion grants (house rent) to the affected families at the rate of NRs 1,000 per month for 4 months. 
- Grant to pay the government la-nd registration fee provided as an incentive to those affected families who purchased replacement land.

- Houseloss compensated at repl-acement cost. Affected households were also provided the construction materials from their old house for reuse.

- Priority of hiring affected family members including local people. Provided employment to 2,568 people during construction. More than three-fourths of the SPAFs/ PAFs were employed and the local-outsider employment ratio in the project was $50-50 \%$ during construction. Both the families' standard of living and the local economy soon exhibited the positive impact of these regular cash inflows during the project construction period.

- Implementation of micro-credit revolving fund program with an earmarked budget of NRs 2,900,000.

- Protection of Setibeni Sheela, a holy stone religious site, by constructing a gabion wall with height ranging from 2 to $8 \mathrm{~m}$, a walking path with railing around the sacred stone to facilitate devotees to worship and encircle the stone.

- Construction of cremation sheds and renovation of temples.

- Implementation of skill development training program.

- Resettlement and rehabilitation of Bote (fisherman) families.

- Implementation of community support program, which includes conservation of local religious and cultural sites, literacy program to local women, support to local schools, renovation and construction of drinking water, etc.

- Establishment of a primary sch- ool at Andhimuhan Bote village, as an important gesture of project mitigation attempts for the Bote community.

- The study shows that the empl-oyed SPAF/ PAFs have secured NRs 128,000 average annual cash income compared to the 22,000 rupees that families earned annually before the project started. This indicates that the cash income of the SPAF/ PAFs was nearly six times greater than the previous cash income.

- Regular celebration of World Environment Day to enhance environmental awareness among local public.

\section{Environmental aspects during operation phase}

The Kali Gandaki 'A' Hydroelectric Plant has been under commercial operation since August 2002. The Environmental and Social Studies Department (ESSD) of the NEA carried out the post-construction Environmental Impact Study of the project. ESSD staff has recently completed operation phase environmental and social monitoring activities of the project for two year (2005-2006) and prepared an Environmental and Social Operation Manual for the project. These activities have been carried out as per ADB requirement, with reports submitted regularly to ADB.

Findings

Major findings of environmental and social monitoring/studies during operation phase of the project include;

1. Release of $4 \mathrm{~m}^{3} / \mathrm{s}$ minimum of water during dry season and $6 \mathrm{~m}^{3} / \mathrm{s}$ on religious days has been observed.

2. A siren warning system is in operation at the powerhouse and dam site.

3. Reduction in bed load below the dam after construction has occurred. However, total sediment loads downstream has not changed from the pre-existing conditions.

4. The KGA project has had a positive effect on forests, with regards to energy consumption, as the use of alternative sources of energy has increased,

5. The post-construction Environmental Impact Audit study indicates that construction disturbances have settled down.

6. The Reservoir Sedimentation Study is being carried out annually by the KGA department. A bathymetric survey of project reservoir by echo sounding technology has been implemented.

7. The fish bypass system is under operation.

8. Fish hatchery operations and management are being carried out smoothly by the Nepal Agricultural Research Council (NARC).

9. Release of different species of fingerling in Project reservoir has been implemented.

10. Three has been a decrease in average land holding size of the affected families in comparison to pre-project levels.

11. The quality of reconstructed houses appears better than old houses. Some of the new houses are roofed with iron-sheeting and are 
cemented, replacing homes that were previously thatched.

12. All the newly built houses have been handed over to the affected Bote (fishermen) families.

13. The Kali Gandaki Primary School for Bote children is operating smoothly with classes up to class 3.

14. The agricultural occupation of affected families has declined by about 5\% whereas service category has increased from $6.90 \%$ to $9.58 \%$. Similarly the occupation levels of labor and wages during pre-project period of $0.54 \%$ have also slightly increased to $0.64 \%$ in post-project period.

15. The intermixing of local and outside laborers created both positive and negative effects. The positive effects reported are the exchange of skills, ideas etc., between groups, while the negative effects reported are some unacceptable socio-cultural behaviors such as theft and disruption in law and order during the project construction period.

16. The local economy is now more integrated with the national economy because of the project access road and the boat transportation on the project reservoir.

17. Implementation of the project has established and enhanced the local infrastructures in the project area, specifically at the dam and powerhouse sites.

18. 225 people were employed during the operation phase. Local employment in the operation phase is about $69 \%$.

19. Due to the fluctuation and peaking effects of the project to the downstream of dam and below the powerhouse site, the sankhar (traditional fishing gear) used by the Bote fisherman to harvest fish has been affected, causing adverse impact on their income and livelihood.

20. There seems to be an improvement in the health status of families, since more houses now have toilets and separate cowsheds. Previously, people and livestock shared common space.

\section{Projects benefits}

Theimplementation of Kali Gandaki 'A' Hydroelectric Project in the region, once considered as remote area, has resulted in multiple beneficial impacts to thelocal community. The improvement of public infrastructure such as access roads, rural electrification, telecommunications and health services, enhanced educational facilities and employment of local population, including projectaffected families during the project construction stage and operation phase, have benefited local communities by enhancing their quality of life.

About 4,256 rural households have benefited from rural electrification in the project areas and additional new households are being electrified.

The project has also implemented Community Support Programs (CSPs) to address the local needs and to build good rapport with local communities, which was not foreseen during project planning. However, the project had also faced difficulties in fulfilling the never-ending demands of the communities, mainly due to the unavailability of funds from alternative sources.

The operation of the project has contributed significantly to Nepal's power system, reducing the need for load shedding, catering to the need of energy for future electrification and boosting economic development of the country. The benefits to government and the local populations include improved infrastructures and employment opportunities. The project has contributed in producing trained and experienced manpower in various skilled job, including environmental monitoring and management of large hydropower projects.

\section{Conclusions}

Most of the proposed requirements set forth in the various project's documents for mitigating adverse environmental impacts due to project construction have been implemented. The impacts of the project due to the access road, rural electrification and employment have created a local transformation. The beneficial impacts of the project have significantly affected at the local, regional and national levels in positive ways.

A considerable amount of cash flow to the local community during project construction ensures at least the previous living standard of PAFs and SPAFs. Most of the PAF and SPAFs have managed to achieve a better standard of living and some have invested money in modernizing houses and purchasing land. Local people, including the affected families, are now more amenable to more commercial activities for income generation.

The project can be considered as a pioneer in the field of environmental monitoring and management of large hydropower project in Nepal.

Rajendra P. Thanju is Deputy Director (Economist) of the Environmental and Social Studies Department, Nepal Electricity Authority. He previously served as socio- 
economist in the Environmental Management Unit of the Kali Gandaki 'A' Hydroelectric Project.

Corresponding address: rpthanju@gmail.com

\section{End notes}

1 Professor Michael M Cernea and Dr. Donald Graybill were members of international POE for social and environmental aspects of the KGA Project, respectively.

2 SPAF: Seriously Project Affected Family denotes the affected families who lost their house or more than $50 \%$ of their income or land.

3 PAF: Project Affected Families denotes the affected families who lost their assets to the project.

\section{References}

ADB (Asian Development Bank), 2004,Completion Report on the Kali Gandaki 'A' Hydroelectric Project (Loan 1452-Nep[Sf]) in Nepal, Manila: Asian Development Bank.

ESSD (Environmental and Social Studies Department), 2003, Post Construction Environmental Impact Audit Study of Kali Gandaki 'A' Hydroelectric Project, Kathmandu: ESSD, Nepal Electricity Authority. , 2005/2006, Environment and Social Monitoring Report of Kali Gandaki 'A' Hydroelectric Project, Kathmandu: ESSD, Nepal Electricity Authority.

KGEMU (Kali Gandaki Environmental Management Unit), 2002, Impoverishment Risks Monitoring and Management in Kali Gandaki 'A' Hydroelectric Project: A Social Synthesis Report, Beltari, Syangja District, Nepal: KGEMU (Kali Gandaki 'A' Hydroelectric Project) and Morrison Knudsen International.

, 2002, Environmental Management and Monitoring in Kali Gandaki 'A' Hydroelectric Project: Environmental Synthesis Report, Beltari, Syangja District, Nepal: KGEMU (Kali Gandaki 'A' Hydroelectric Project) and Morrison Knudsen International.
MKI (Morrison Knudsen International), 1996, Environmental Impact Assessment, Final Report, Kathmandu: Kali Gandaki 'A' Associates- Morrison Knudsen Corporation (USA), Norconsult International (Norway) and IVO International, Ltd. (Finland).

, 1996, Mitigation Management and Monitoring Plan, Kathmandu: MKI (Kali Gandaki 'A' Hydroelectric Project) and Nepal Electricity Authority. 